\title{
Perancangan Sistem Informasi Akuntansi Pembelian Barang Pada PT Bangun Prestasi Bersama Jakarta
}

\author{
Ari Puspita ${ }^{1}$, Yuyun Yuningsih ${ }^{2}$, Muhammad Fahmi $^{3}$, Yuli Wahyuni ${ }^{4}$
}

\begin{abstract}
Advances in science and technology have encouraged changes in all fields, one of which is purchasing goods. In the past, the purchase of goods was carried out directly in a place, but now the activities of purchasing goods can be carried out indirectly through the information technology media. This final project discusses the application of purchasing goods data processing at PT Bangun Prestasi Bersama, where in the purchase of goods the transaction recording activities have not used the application system so that sometimes there are errors in calculation, recording purchase data, loss of input and output documents and length of time in preparing monthly reports. The application was designed with the aim of being able to process supplier data, data on goods, order transactions, purchase transactions, and print reports. Reports produced by this application include supplier data reports, inventory reports, goods order transaction reports, and goods purchase transaction reports. The application of the data processing application for purchasing goods is expected to be a solution that can overcome the problems that exist during the process of purchasing goods at PT Bangun Prestasi Bersama, so that the purchase transaction process that occurs can be organized properly, the activities of purchasing goods can be run according to the procedure.
\end{abstract}

Intisari - Kemajuan ilmu dan teknologi telah mendorong terjadinya perubahan dalam semua bidang, salah satunya adalah kegiatan pembelian barang. Dahulu kegiatan pembelian barang dilakukan langsung di sebuah tempat, tapi sekarang kegiatan pembelian barang dapat dilakukan secara tidak langsung melalui media teknoligi informasi. Tugas akhir ini membahas mengenai aplikasi pengolahan data pembelian barang pada PT Bangun Prestasi Bersama, dimana dalam kegiatan pembelian barang pencatatan transaksikegiatannya belum menggunakan sistem aplikasi sehingga kadang terjadi kesalahan dalam penghitungan, pencatatan data pembelian, kehilangan dokumen masukan dan keluaran serta lama dalam menyusun laporan bulanan. Aplikasi yang dirancang bertujuan dapat mengolah data supplier, data barang, transaksi pemesanan barang, transaksi pembelian barang, dan mencetak laporan. Laporan yang dihasilkan aplikasi ini antara lain, laporan data supplier, laporan stok barang, laporan transaksi pemesanan barang, dan laporan transaksi pembelian barang.

Program Studi Sistem Informasi, Fakultas Teknologi Informasi Universitas Bina Sarana Informatika, Jl. Kramat Raya No.98, RT.2/RW.9, Kwitang, Jakarta Pusat 10450, Telp.(021)23231170, Fax(021)21236158, email : ari.arp@bsi.ac.id

${ }^{2}$ Program Studi Sistem Informasi, STMIK Nusa Mandiri, Jl. Jatiwaringin Raya No. 2 Jakarta Timur Telp. (021) 28534471, 28534390,email:yuyun.yyg@nusamandiri.ac.id

${ }^{3}$ Program Studi Teknik Informatika, STMIK Nusa Mandiri, Jl. Jatiwaringin Raya No. 2 Jakarta Timur, Telp. (021) 28534471, 28534390,email:fahmi.mmf@nusamandiri.ac.id

${ }^{4}$ Program Studi Teknologi Komputer, Fakultas Sekolah Vokasi Universitas Pakuan, Jl. Pakuan P.O. Box 452 Bogor 16143 Telp (0251)8362701 (Hunting),email :yuli_wahyuni@unpak.ac.id
Penerapan aplikasi pengolahan data pembelian barang ini diharapkan menjadi solusi yang dapat mengatasi permasalaha yang ada saat proses pembelian barang pada PT Bangun Prestasi Bersama, sehingga proses transaksi pembelian barang yang terjadi akan dapat di organisir dengan baik, kegiatan pembelian barang dapat dapat berjalan sesuai dengan prosedur.

Kata Kunci - Aplikasi, Pengolahan Data, Pembelian Barang.

\section{PENDAHULUAN}

Perkembangan ilmu dan teknologi pada saat ini, telah mendorong terjadinya perubahan dalam segala bidang, salah satunya kegiatan pembelian barang. Dahulu kegiatan pembelian barang dilakukan secara langsung di sebuah tempat seperti pasar, took dan tempat lainnya. Akan tetapi saat kegiatan pembelian barang dapat dilakukan secara tidak langsung melalui media teknologi informasi atau lebih dikenal dengan sebutan online shoping.

Penerapan sistem informasi pada lembaga bisnis saat ini telah menjadi kebutuhan dalam merebut pasar global yang semakin pesat, baik perangkat hardware maupun software yang dfasilitas dengan jaringan internet, membuat semua orang dalam segala bidang dapat mengetahui informasi apa saja yang mereka inginkan dan butuhkan dengan sangat cepat dan mudah. Sementara itu seiring dengan berkembangnya pembangunan, organisasi-organisasi publik maupun swasta, baik di bidang bisnis maupun di bidang pariwisata semakin banyak yang mampu memanfaatkan teknologi informasi, dapat menunjang efektivitas, produktivitas dan efesiensi dari setiap usahanya. Berkat kemajuan teknologi komunikasi dan informasi saat ini, pesan-pesan dapat dikirim dan diterima pada waktu yang bersamaan meskipin jarak antara pengirim dan penerimanya berjauhan, arus informasi dalam kehidupan manusia modern tidak mungkin lagi dapat dibatasi (Siswanto, 2017)

Dalam proses pembelian barang, perusahaan mencatat dan mendata kegiatan pembelian antara lain mendata pelanggan, menerima pesanan barang, mencatat transaksi, menyimpan dokumen, pembuatan laporan bulanan dan lain-lain. Pencatatan kegiatan tersebut masih menggunakan Microsoft word atau microsoft excel dan belum menggunakan sistem aplikasi sehingga kadang terjadi kesalahan dalam penghitungan, pencatatan data pembelian, kehilangan dokumen masukan dan keluaran serta lama dalam menyusun laporan bulanan. Namun pada kenyataannya masih banyak perusahaan yang sistem pembelian barang, Pencatatan data kegiatan pembelian, data pelanggan, data pesanan barang, pencatatatan transaksi, penyimpanan dokumen, pembuatan laporan bulanan dan lain-lain, masih belum menggunakan sistem yang telah terkomputerisasi dengan baik. Hal ini disebabkan kerena masih kurangnya pengetahuan pegawai 
mengenal hubungan manajemen perusahaannya dengan sistem komputer. Dengan adanya komputer, perusahaan dapat melakukan proses penyimpanan data dengan mudah dan cepat, karena tingkat kecepatan dan penyimpanan data pada komputer menjadi lebih aman dan rapi, sehingga mudah kembali menemukan kembali daya yang diinginkan.

Permasalahan-permasalahan yang sering timbul dalam sistem pembelian pada PT. Bangun Prestasi Bersama Jakarta adalah : Proses Pencatatan data pembelian dan penyimpanan data pembelian banyak kekurangan dan menjadi lama dalam pembuatan laporan. Adanya kesalahan pada saat mengolah data Keamanan yang kurang, sehingga sering kehilangan data. Dari latar belakang diatas, maka tujuan dari penelitian ini adalah mengurangi kesalahan dalam pengolahan data, dan keamanan data pembelian tidak mudah hilang serta menyusun laporan bulanan secara cepat dan tepat.

\section{TEORI PENDUKUNG}

\section{A. Pengertian Sistem Informasi}

Suatu sistem pada dasarnya adalah sekelompok unsur yang erat hubungannya satu dengan yang lain, yang berfungsi bersama-sama untuk mencapai tujuan tertentu. [1]

Sistem mengandung arti kumpulan-kumpulan dari komponen-komponen yang dimiliki unsur keterkaitan antara satu dengan yang lainnya. [2] Sistem adalah kumpulan elemen yang saling berhubungan dan saling berinteraksi satu sama lain untuk mencapai satu tujuan tertentu [3].

\section{B. Pengertian Sistem Informasi Akuntansi}

Sistem Informasi Akuntansi (SIA) adalah sistem informasi yang menggunakan seperangkat komputer untuk mengolah data keuangan yang berhubungan dengan data transaksi dalam siklus akuntansi serta penyajiannya dalam bentuk laporan keuangan kepada manajemen perusahaan [4].

Sistem Informasi Akuntansi memiliki beberapa komponen yang saling terhubung yaitu [4] :

1. Sumber daya manusia (SDM) yang terlatih yang memahami bisnis proses akuntansi dan keuangan secara umum.

2. Prosedur keuangan dan akuntansi

3. Formulir Data Keuangan, yang digunakan untuk mencatat seluruh aktifitas keuangan berupa transaksi kas, aktiva tetap, hutang, piutang, persediaan, penjualan, biaya, dan lain-lain

4. Accounting Software, misalnya MYOB, Zahir, Oracle Finance, Accurate

5. Seperangkat komputer yang terhubung dengan jaringan (Networking), dan kelengkapan pendukung lainnnya

\section{METODE PENELITIAN}

Metode penelitian yang penulis lakukan dalam penelitian untuk penulisan jurnal ini sebagai berikut:

\section{Metode Pengumpulan Data}

a. Pengamatan

Penulis mengamati secara langsung aktifitas proses pembelian barang pada PT Bangun Prestasi Bersama yang sedang berjalan b. Wawancara

Metode ini merupakan cara pengumpulan data melalui wawancara langsung atau tanya jawab dengan pihak yang terkait dengan pembelian barang pada PT Bangun Prestasi Bersama

c. Studi pustaka

Pada penelitian ini penulis mengawali kajian dengan melihat jurnal-jurnal dari peneliti-peneliti sebelumnya, dan sumber-sumber atau bahan lainnya yang berhubungan dengan tema penelitian yang penulis ambil Untuk dijadikan sebagai bahan referensi dan acuan dalam melakukan penelitian ini.

\section{Metode Pengembangan Software}

Dalam pengembangan software ini penulis menggunakan metode Waterfall. Model SDLC waterfall sering disebut juga model sekuensial linier (sequential linear) atau alur hidup klasik (classic life cycle). Model Waterfall menyediakan pendekatan alur perangkat lunak secara terurut dimulai dari analisis, desain, pengodean, pengujian, sampai dengan tahap pendukung [5].

Menurut Sommerville tahapan utama yang langsung mencerminkan dasar pembangunan kegiatan pada metode waterfall adalah sebagai berikut : [6]

a. Requirements definition

Mengumpulkan apa yang dibutuhkan secara lengkap untuk kemudian dianalisis guna mendefinisiskan kebutuhan yang harus dipenuhi oleh program yang akan dibangun. Fase ini harus dikerjakan dengan lengkap untuk menghasilkan desain yang lengkap.

b. System and software design

Setelah yang dibutuhkan telah selesai dikumpulkan dan sudah lengkap maka desain kemudian dikerjakan.

c. Implementation and unit testing

Desain program diterjemahkan dalam kodekode dengan menggunakan Bahasa pemrograman yang sudah ditentukan program yang dibangun langsung diuji secara unit, apakah sudah bekerja dengan baik.

Jenis Penelitian yang penulis buat merupakan pendekatan kualitatif dan penelitian terapan [7]. Tempat Penelitian dilakukan pada PT Bangun Prestasi Bersama Jakarta, yang beralamat di Perkantoran Fatmawati Mas Blok I/118 Jl. Fatmawati Raya No.20, Jakarta Selatan. Waktu Penelitian yang digunakan Penulis dari tanggal 16 September 2019 sampai dengan 16 Desember 2020.

\section{Model Pengembangan Sistem}

Pada Bab ini penulis menjelaskan mengenai langkah langkah dalam melakukan penelitian kuantitatif yaitu sebagai berikut :

a. Tahapan Analisis kebutuhan software

Pada Tahap ini Penulis mengumpulkan data kebutuhan yang akan digunakan untuk spesifikasi perangkat lunak, agar dapat dipahami dan sesuai dengan apa yang dibutuhkan oleh user. 
b. Tahapan Desain

Pada Tahapan ini Penulis mendesain perangkat lunak, dengan menggunakan peralatan pendukung yang digunakan untuk menggambarkan bentuk logika model dari suatu sistem dengan menggunakan simbol-simbol dan diagram-diagram yang menunjukan secara tepat arti dan fungsinya. Peralatan Pendukung yang Penulis Gunakan antara lain: Entity Relationship Diagram (ERD), Logical Relational Structure (LRS), Activity Diagram dan Sequence Diagram.

c. Tahapan Pembuatan Kode Program

Pada tahapan ini penulis menggunakan XAMPP sebagai web server yang dengan mudah digunakan serta dapat melayani tampilan halaman web yang dinamis, Bahasa pemrograman yang penulis gunakan adalah bahasa pemrograman Java dan aplikasi yang digunakan untuk membuat desain program serta sebagai editor untuk bahasa programnya adalah Netbeans IDE.

d. Tahapan Pengujian

Dalam pengujian ini penulis menggunakan metode blackbox testing dengan memberikan masukan-masukan kepada sistem atau program yang dibuat, apakah keluaran dari program yang dibuat sesuai dengan apa yang diharapkan atau tidak. Pengujian ini dilakukan untuk meminimalisir kesalahan dan memastikan keluaran dari program telah sesuai dengan yang diinginkan.

e. Pendukung (support) atau Pemiliharaan (maintenance) Setelah sistem atau program selesai dibuat, tidak menutup kemungkinan akan ada perubahan sistem setelah diterima pengguna, hal ini terjadi karena ada kesalahan yang terjadi dan tidak keluar ketika dilakukan pengujian. Pada tahap ini penulis akan memperbaiki kesalahan tersebut.

\section{HASIL DAN PEMBAHASAN}

A. Analisis Kebutuhan Software

Analisis kebutuhan software merupakan awal dari langkah yang akan dilakukan dalam proses mengembangkan atau membuat sebuah software, dengan cara menganalisa kebutuhan-kebutuhan yang akan dijadikan sebagai bahan masukan dalam pembuatan software tersebut. Dengan mengetahui bahan masukan yang diperlukan dan keluaran yang diinginkan maka diharapkan software yang dibuat akan mudah digunakan dan mudah dipahami oleh penggunanya.

Analisa kebutuhan pengguna untuk sistem pembelian barang pada PT Bangun Prestasi Bersama diusulkan dengan beberapa prosedur antara lain:

1. User

a. User melakukan login

b. User mengelola data supplier

c. User mengelola data barang

d. User mengelola pemesanan barang

e. User mengelola pembelian barang

f. User menampilkan laporan data supplier

g. User menampilkan laporan stok barang

h. User menampilkan laporan pemesanan barang

i. User menampilkan laporan pembelian barang

j. User melakukan logout
2. Direksi

a. Direksi melakukan login

b. Direksi menampilkan laporan data supplier

c. Direksi menampilkan laporan stok barang

d. Direksi menampilkan laporan pemesanan barang

e. Direksi menampilkan laporan pembelian barang

f. Direksi melakukan logout

B. Desain

1. Perancangan Database

Tahapan desain ini dapat dilakukan dengan penggambaran Sistem Informasi dengan perancangan database. Menurut Fathansyah Perancangan basis data menghasilkan pemetaan tabel-tabel yang digambarkan dengan Entity Relationship Diagram (ERD) [8].

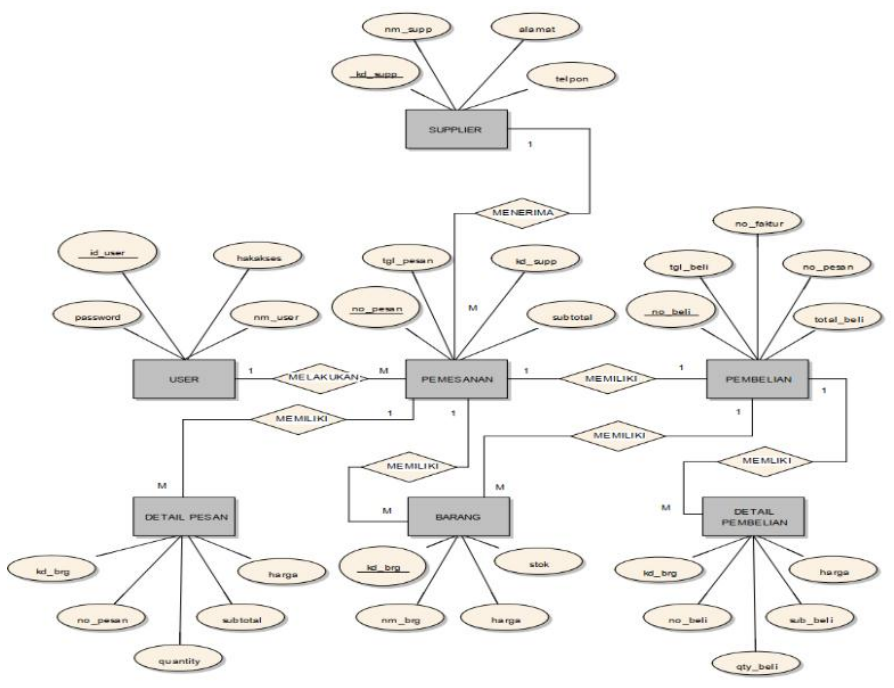

Gbr 1. Entity Relationship Diagram (ERD)

2. Perancangan Activity Diagram

Sistem Informasi Pembelian Barang pada PT Bangun Prestasi Bersama mempunyai Activity Diagram

a. Activity Diagram User/Direksi Melakukan Login

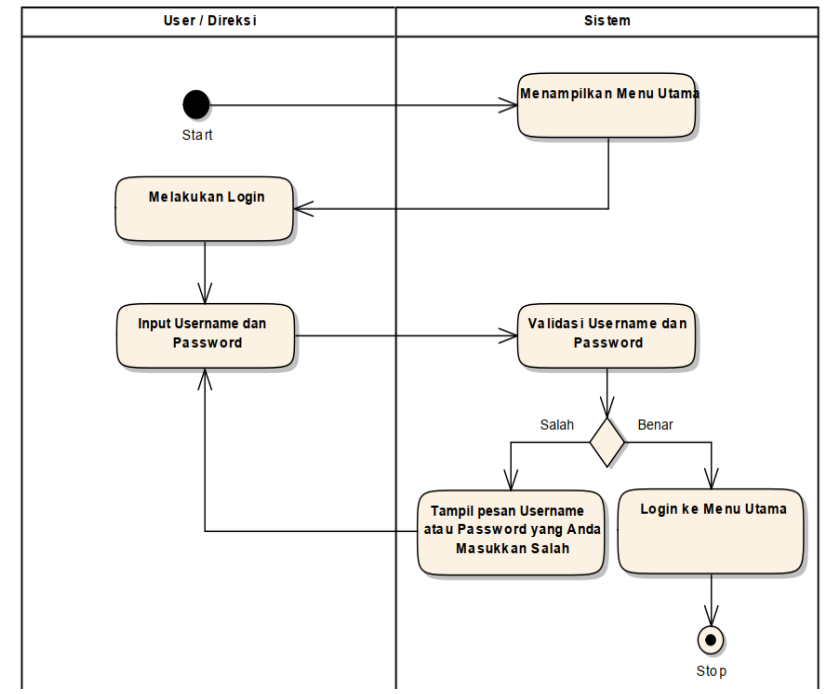

Gbr 2. Activity Diagram User/Direksi Melakukan Login 
b. Activity Diagram User Mengelola Data Supplier

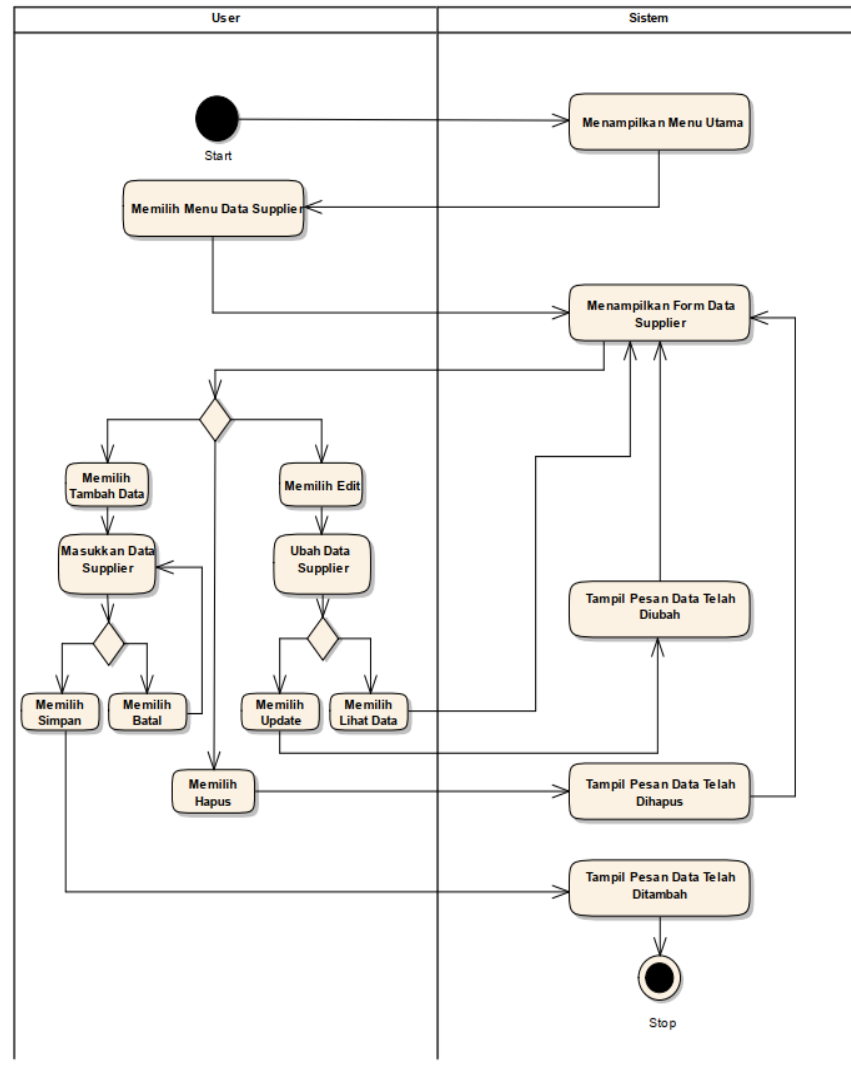

Gbr 3. Activity Diagram User Mengelola Data Supplier

c. Activity Diagram User Mengelola Data Barang

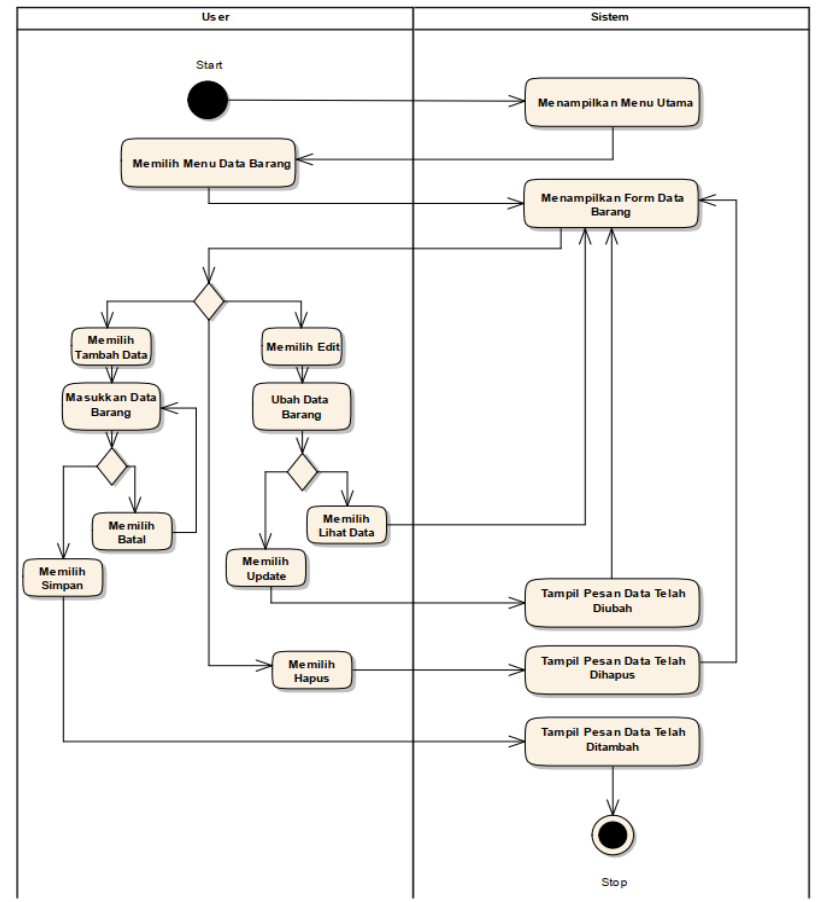

Gbr 4. Activity Diagram User Mengelola Data Barang d. Activity Diagram User Mengelola Transaksi Pemesanan Barang

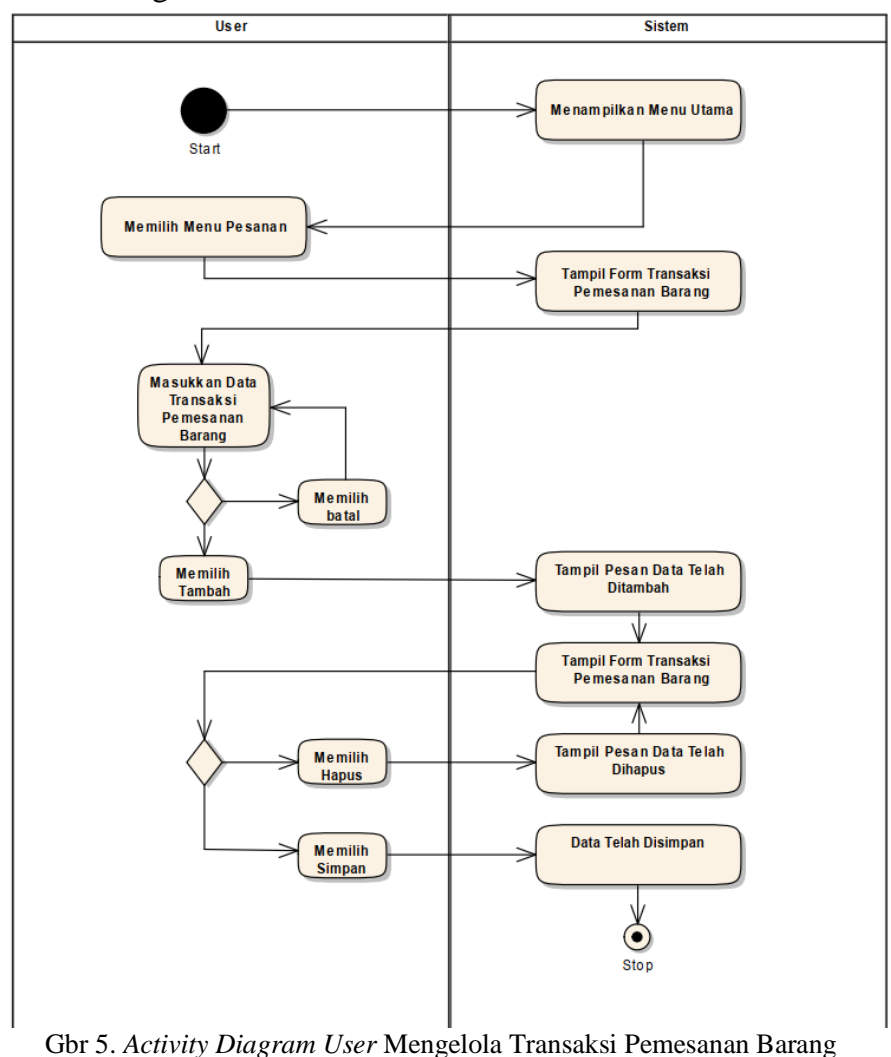

Gbr 5. Activity Diagram User Mengelola Transaksi Pemesanan Barang

e. Activity Diagram User Mengelola Transaksi Pembelian Barang

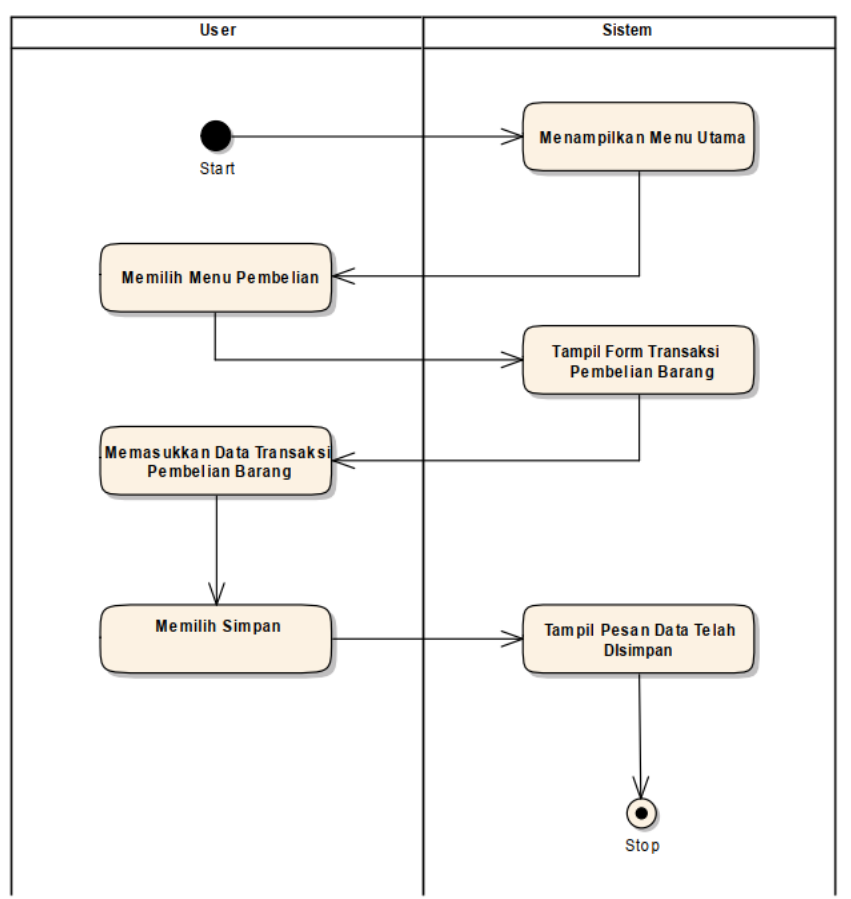

Gbr 6. Activity Diagram User Mengelola Transaksi Pembelian Barang 
f. Activity Diagram User/Direksi Menampilkan Laporan Data Supplier

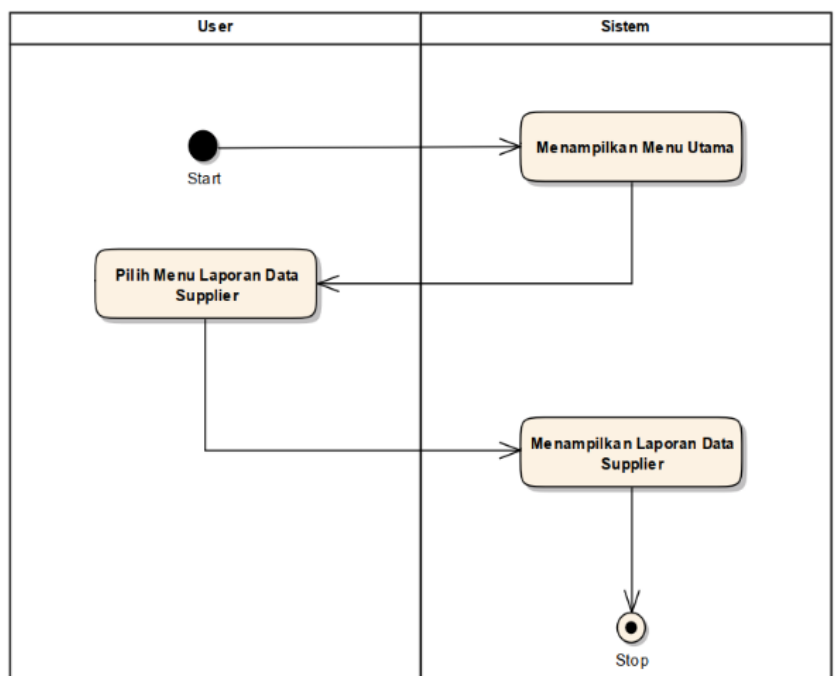

Gbr 7. Activity Diagram User/Direksi Menampilkan Laporan Data Supplier

g. Activity Diagram User/Direksi Menampilkan Laporan Pemesanan Barang

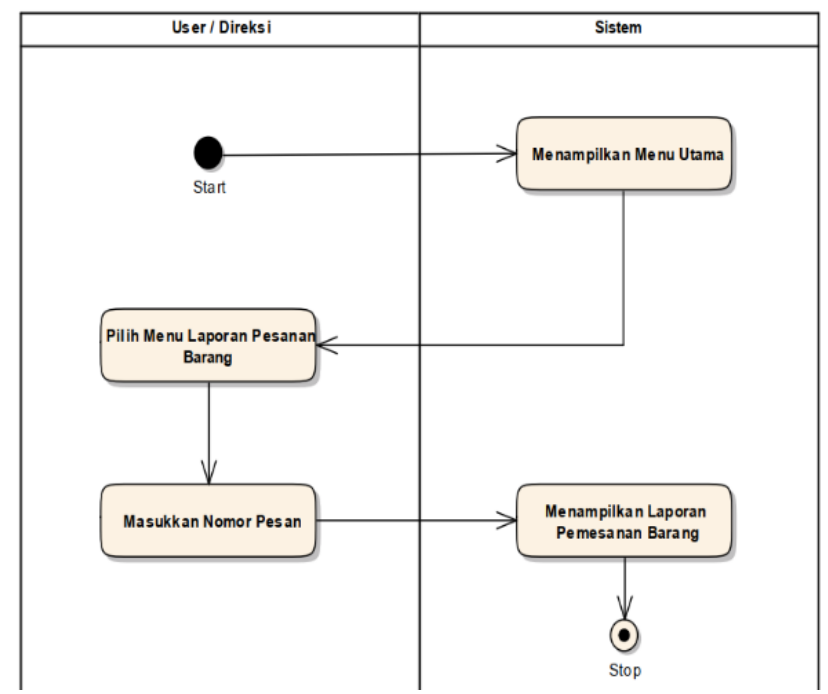

Gbr 8. Activity Diagram User/Direksi Menampilkan Laporan Pemesanan Barang

h. Activity Diagram User/Direksi Menampilkan Laporan Pembelian Barang

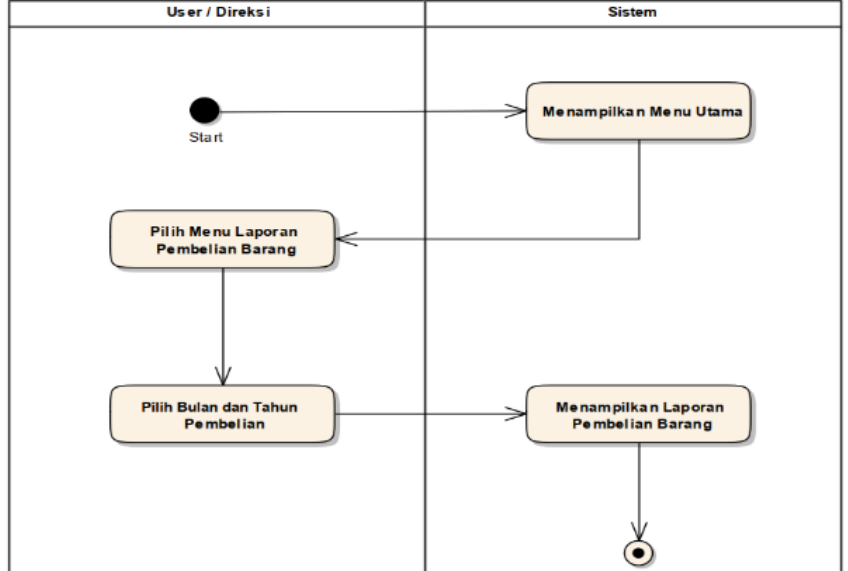

Gbr 9. Activity Diagram User/Direksi Menampilkan Laporan Pembelian Barang

i. Activity Diagram User/Direksi Menampilkan Laporan Stok Barang

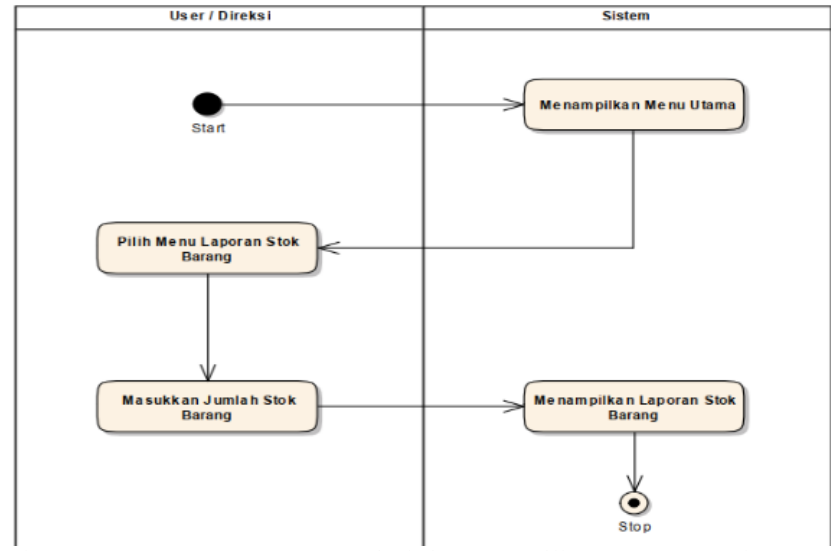

Gbr 10. Activity Diagram User/Direksi Menampilkan Laporan Stok Barang

j. Activity Diagram User/Direksi Logout

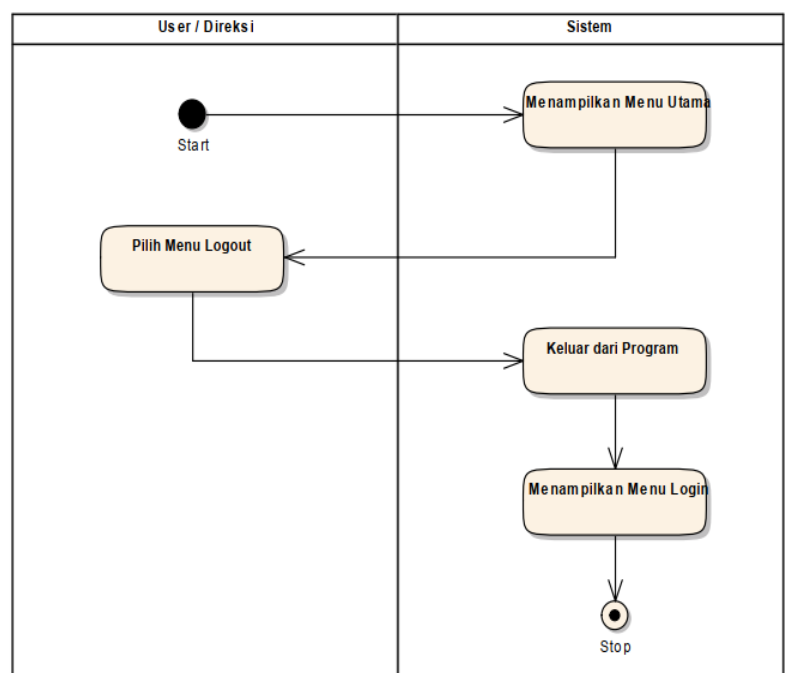

Gbr 11. Activity Diagram User/Direksi Logout 
3. Perancangan Class Diagram

Sistem Informasi Pembelian Barang pada PT Bangun Prestasi Bersama mempunya Class Diagram

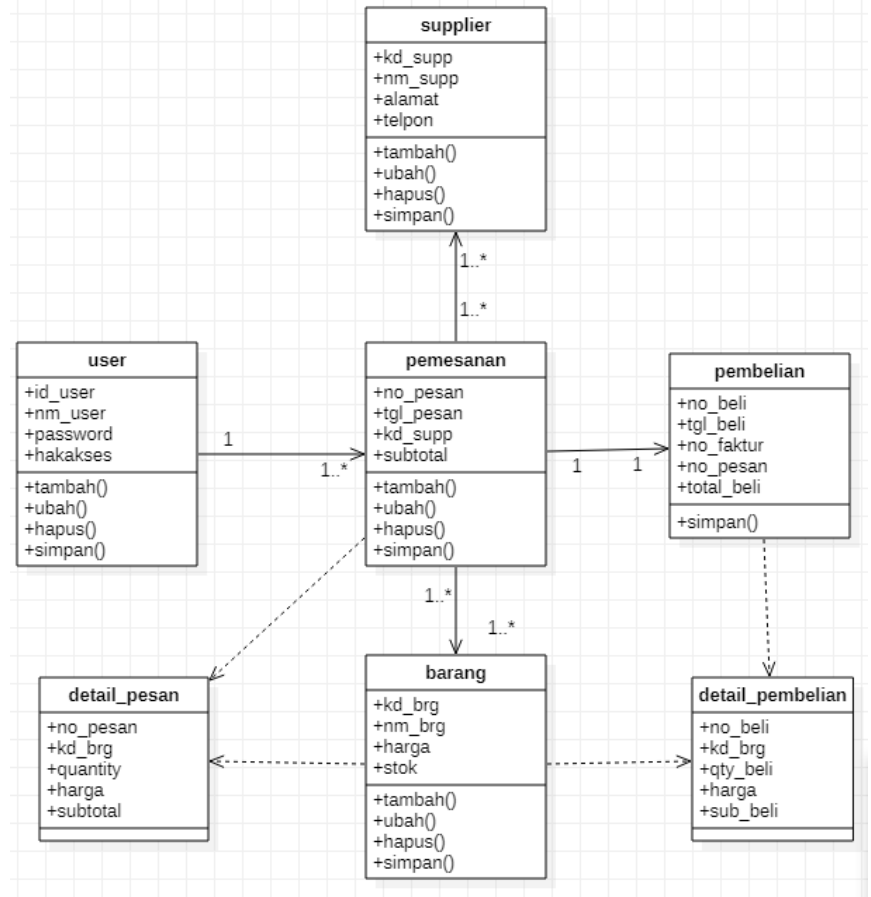

Gbr 12. Class Diagram

4. Sequence Diagram

Sistem Informasi Pembelian Barang pada PT Bangun Prestasi Bersama memiliki Sequence Diagram

a. Sequence Diagram Login

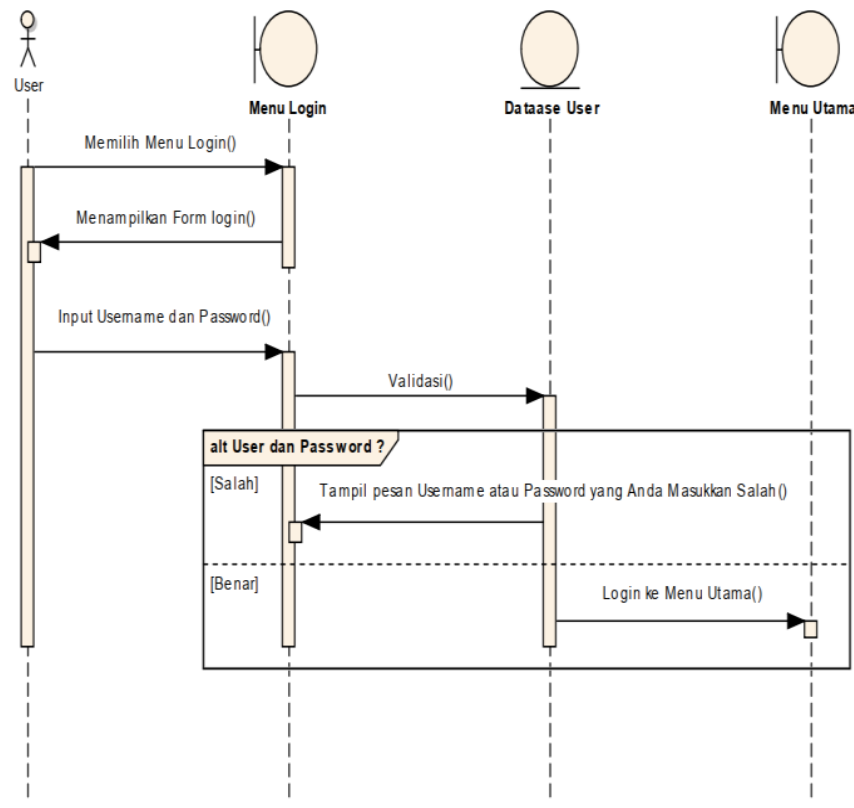

Gbr 13. Sequence Diagram Login b. Sequence Diagram Supplier

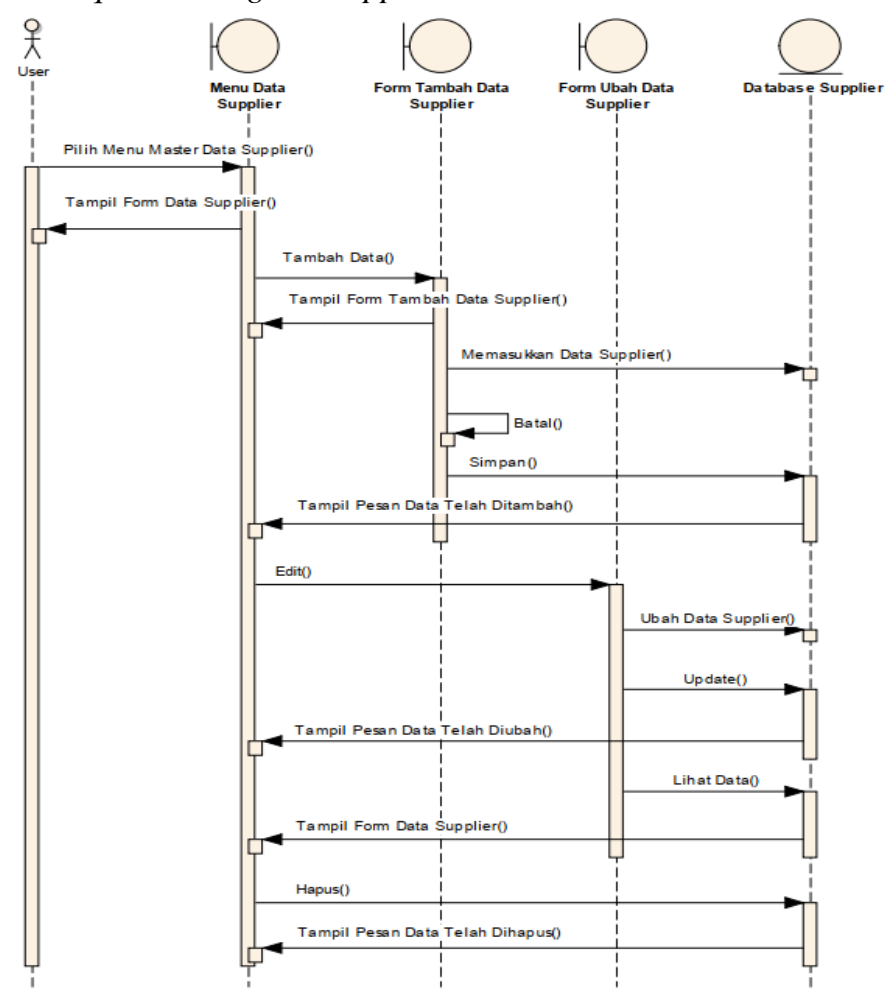

Gbr 14. Sequence Diagram Supplier

c. Sequence Diagram Barang

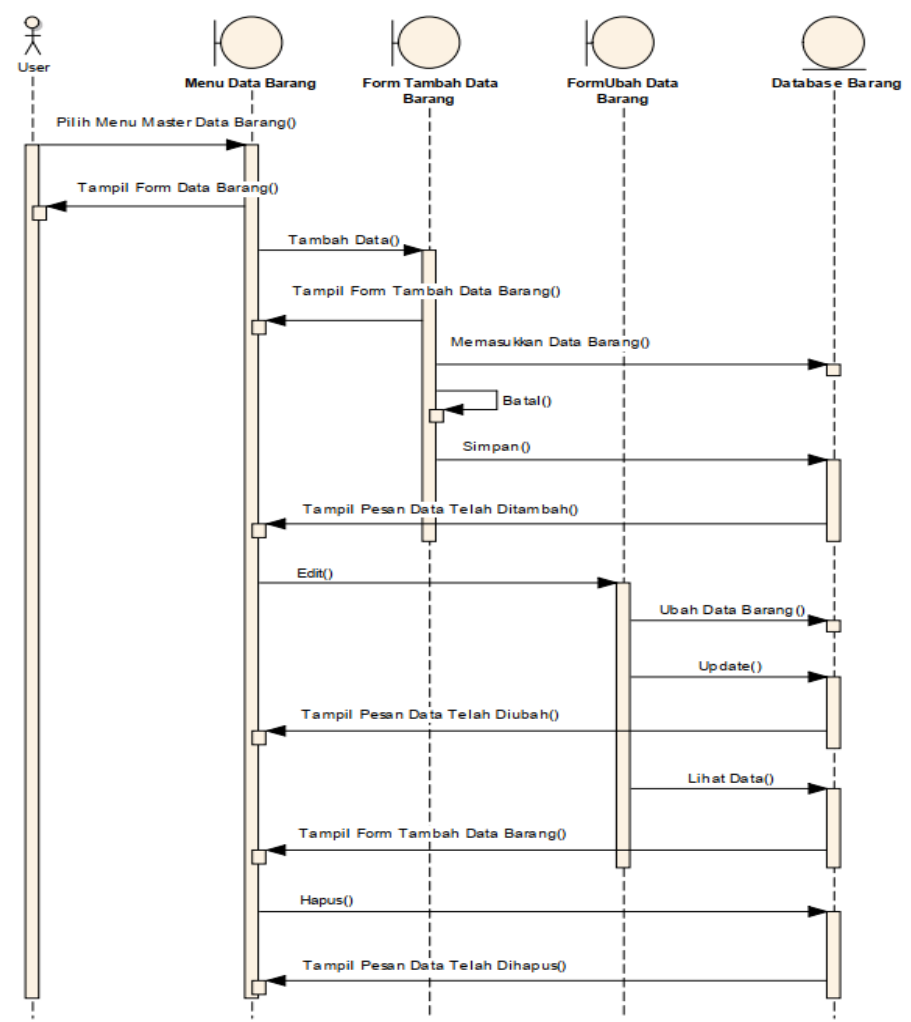

Gbr 15. Sequence Diagram Barang 
d. Sequence Diagram Pesanan

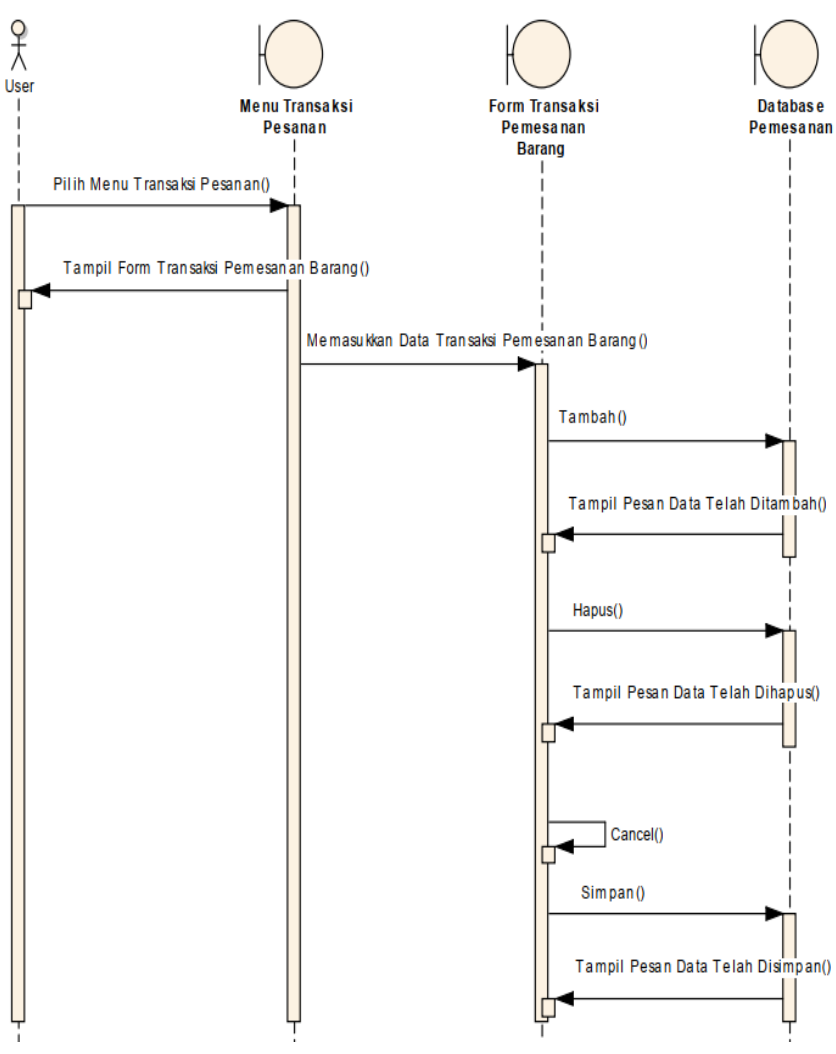

Gbr 16. Sequence Diagram Pesanan

e. Sequence Diagram Pembelian

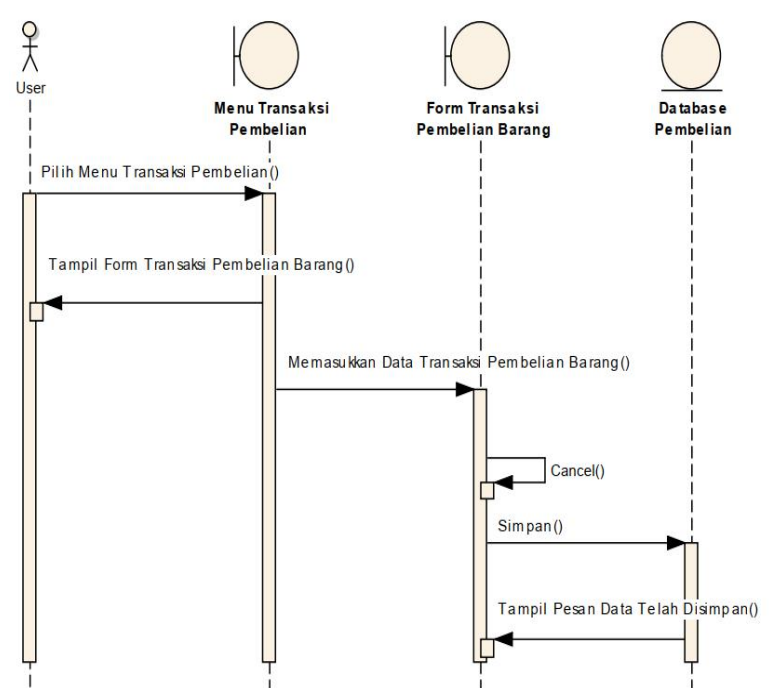

Gbr 17. Sequence Diagram Pembelian f. Sequence Diagram Laporan

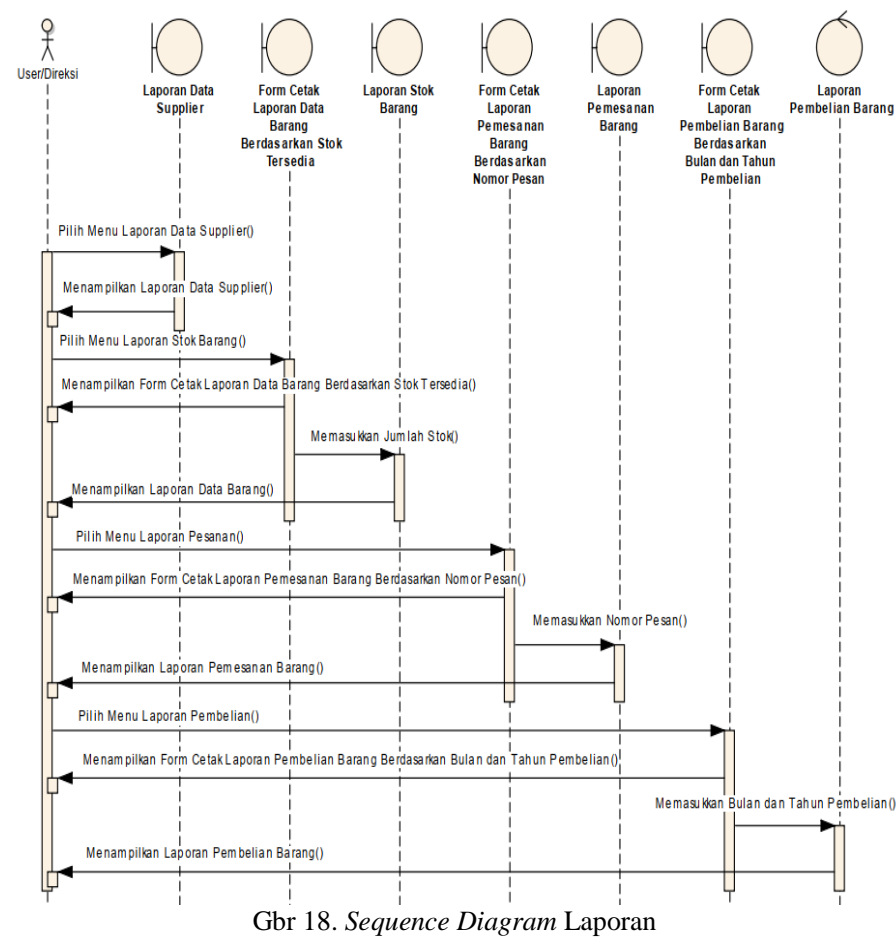

g. Sequence Diagram Logout

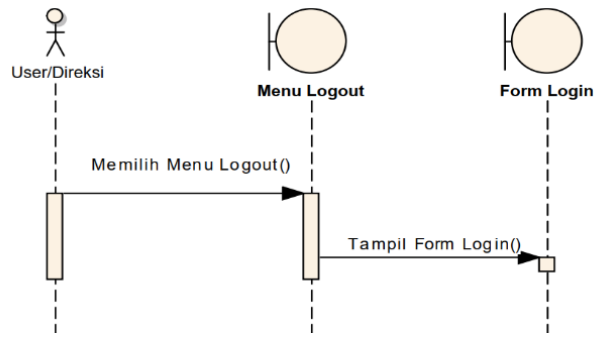

Gbr 19. Sequence Diagram Logout

5. Deployment Diagram

Sistem Informasi Pembelian Barang pada PT Bangun Prestasi Bersama memiliki Deployment Diagram

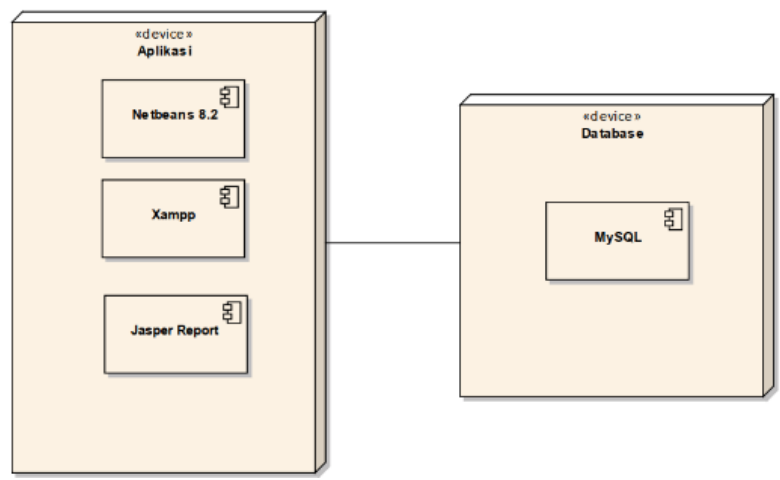

Gbr 20. Deployment Diagram 


\section{Component Diagram}

Sistem Informasi Pembelian Barang pada PT Bangun Prestasi Bersama memiliki Component Diagram

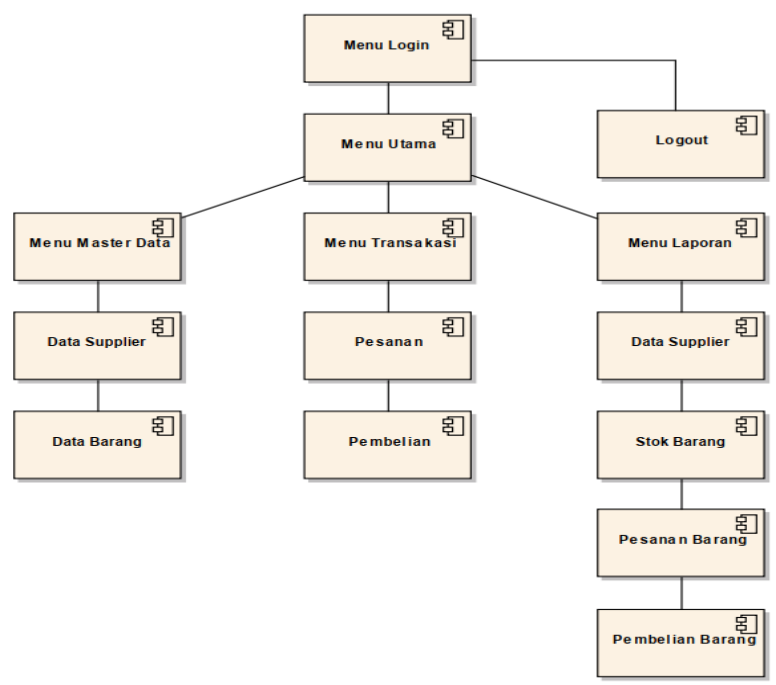

Gbr 21. Component Diagram

7. Perancangan User Interface

Berikut ini merupakan tampilan User Interface dari Perancangan Sistem Informasi Pembelian Barang pada PT Bangun Prestasi Bersama

a. Tampilan Form Login

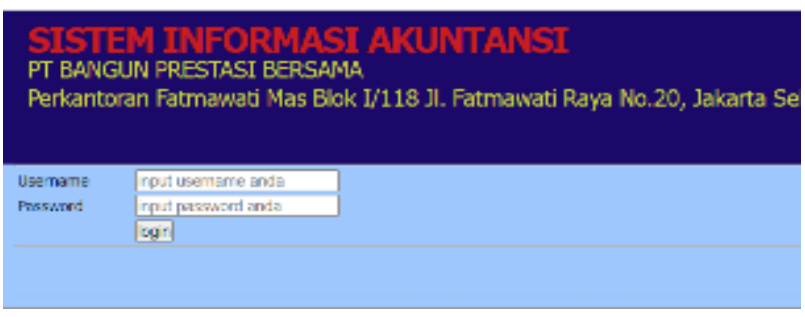

Gbr 22. Tampilan Form Login

b. Tampilan Menu Utama User

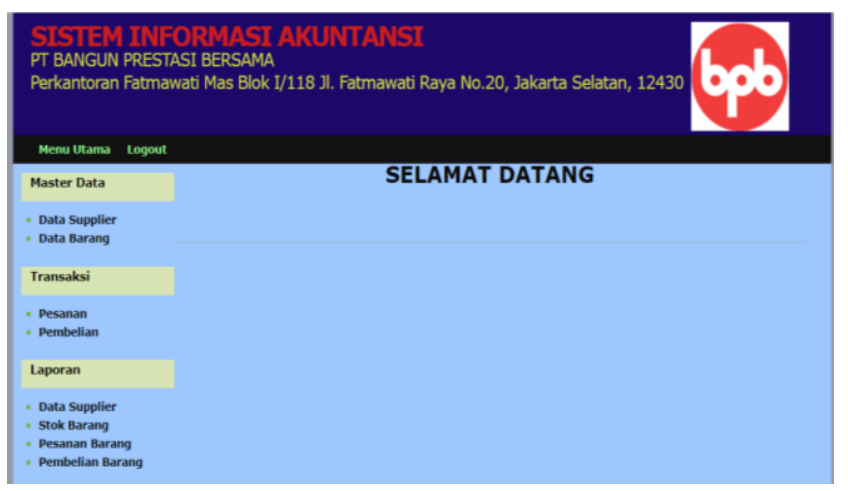

Gbr 23. Tampilan Menu Utama User c. Tampilan Menu Utama Direksi

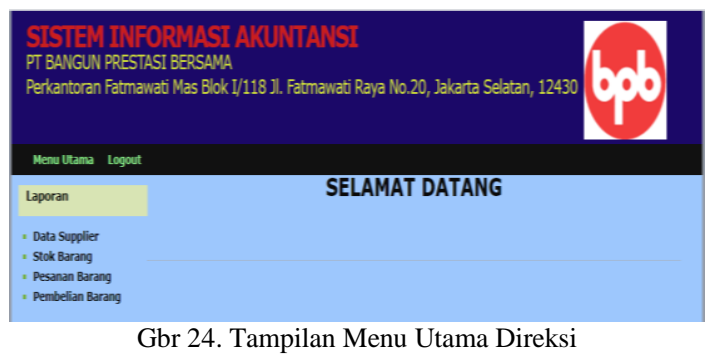

d. Tampilan Form Master Data Supplier

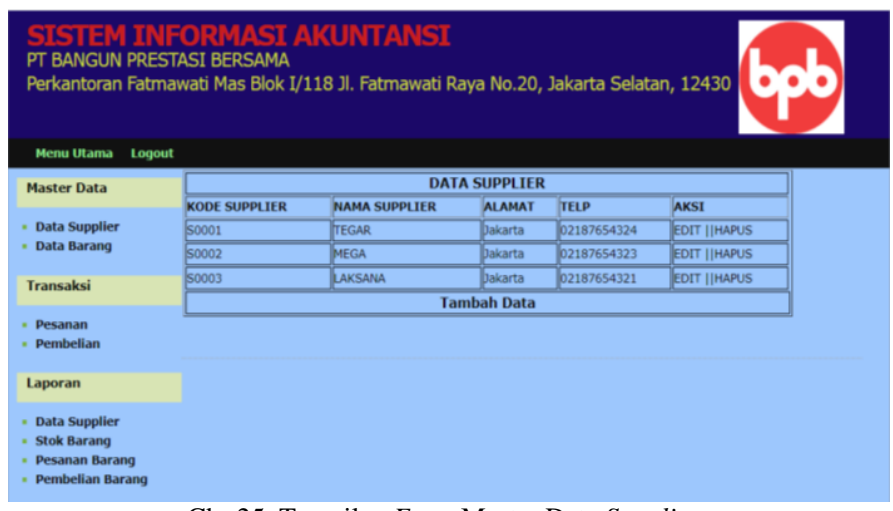

Gbr 25. Tampilan Form Master Data Supplier

e. Tampilan Form Tambah Data Supplier

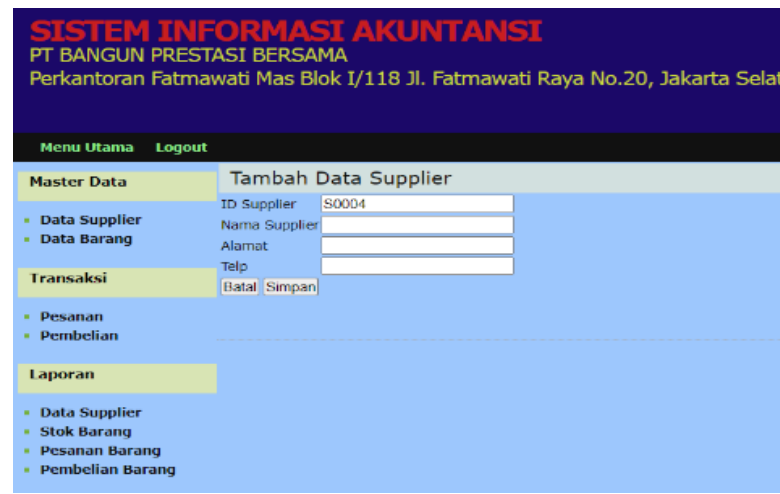

Gbr 26. Tampilan Form Tambah Data Supplier

f. Tampilan Form Ubah Data Supplier

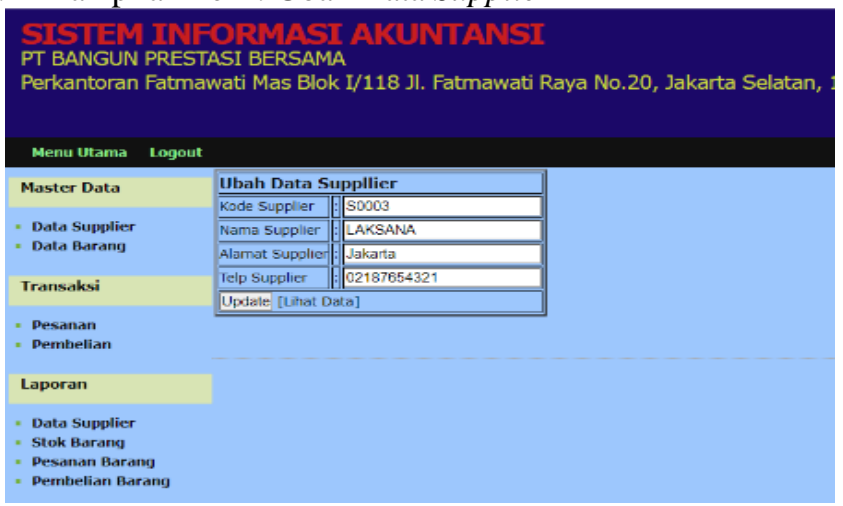

Gbr 27. Tampilan Form Ubah Data Supplier 
g. Tampilan Form Master Data Barang

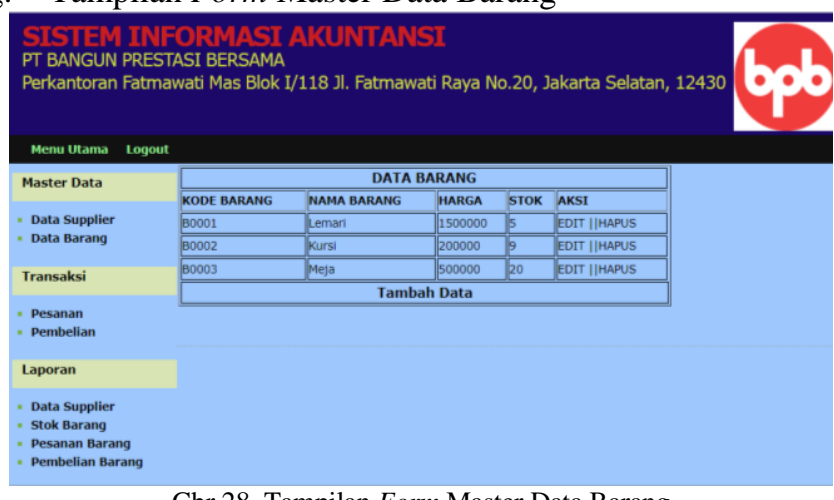

Gbr 28. Tampilan Form Master Data Barang

h. Tampilan Form Tambah Data Barang

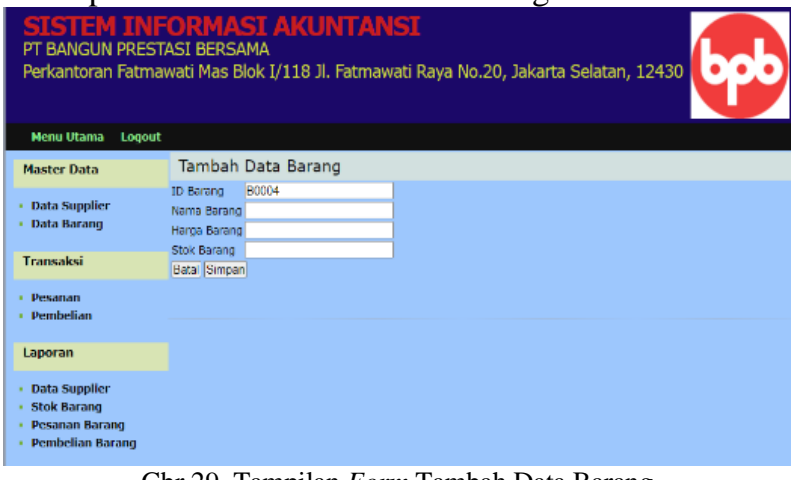

Gbr 29. Tampilan Form Tambah Data Barang

i. Tampilan Form Ubah Data Barang

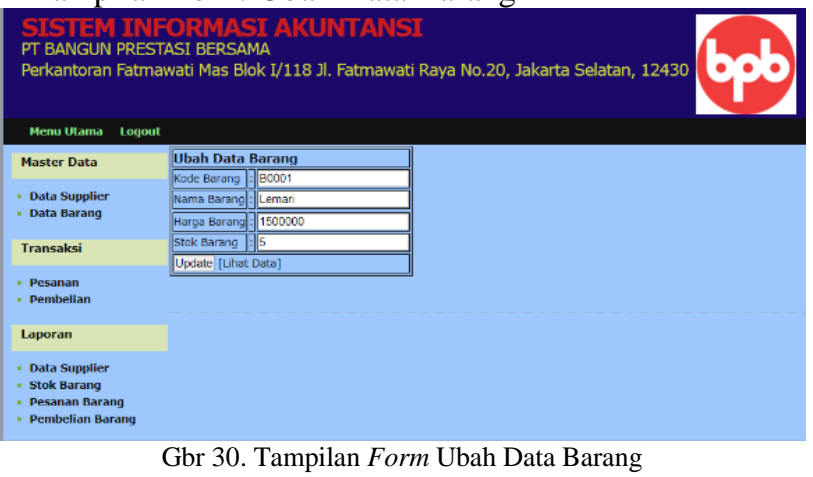

j. Tampilan Form Pemesanan Barang

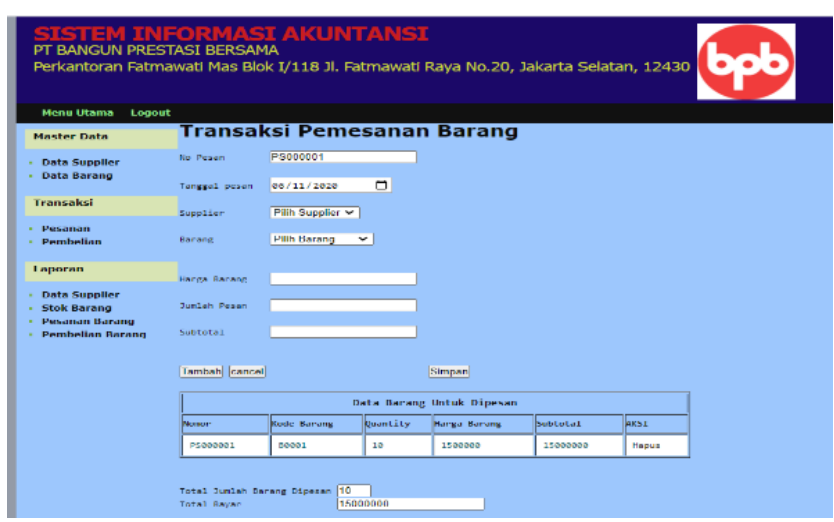

Gbr 31. Tampilan Form Pemesanan Barang k. Tampilan Form Pembelian Barang

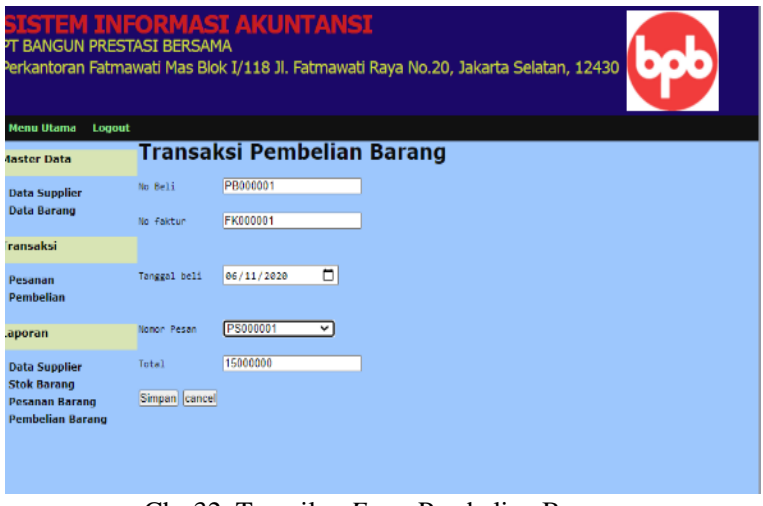

Gbr 32. Tampilan Form Pembelian Barang

1. Tampilan Laporan Data Supplier

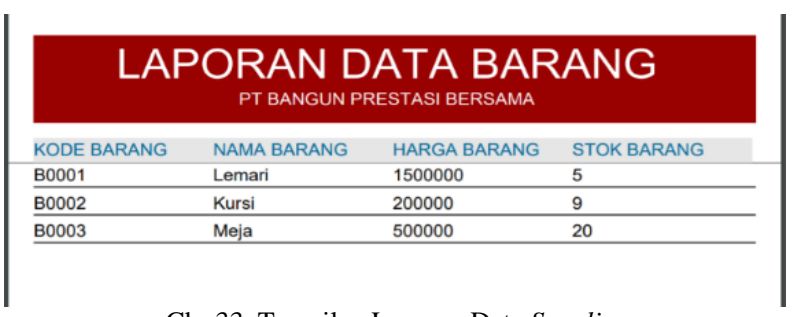

Gbr 33. Tampilan Laporan Data Supplier

m. Tampilan Laporan Pemesanan Barang

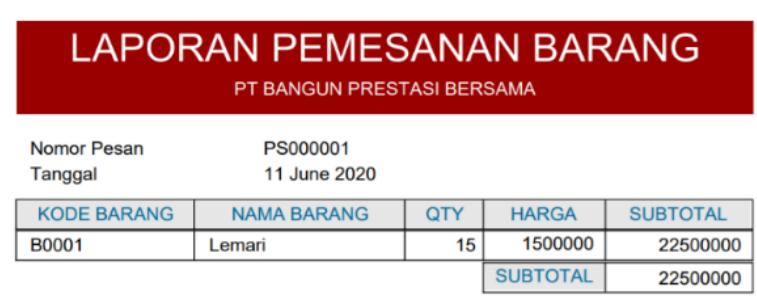

Gbr 34. Tampilan Laporan Pemesanan Barang

n. Tampilan Laporan Pembelian Barang

\begin{tabular}{|c|c|c|c|c|c|c|}
\hline \multicolumn{7}{|c|}{$\begin{array}{l}\text { LAPORAN PEMBELIAN BARANG } \\
\text { PT BANGUN PRESTASI BERSAMA }\end{array}$} \\
\hline Bulan Jun & & Tahun 2020 & & & & \\
\hline TANGGAL & NO FAKTUR & KODE BARANG & NAMA BARANG & QTY & HARGA & SUBTOTAL \\
\hline 11 June 2020 & FK000001 & B0001 & Lemari & 150000 & 1500000 & 22500000 \\
\hline 11 June 2020 & FK000002 & B0002 & Kursi & 200000 & 200000 & 3000000 \\
\hline 11 June 2020 & FK000003 & B0003 & Meja & 500000 & 500000 & 7500000 \\
\hline 11 June 2020 & FK000003 & B0003 & Meja & 500000 & 500000 & 5000000 \\
\hline
\end{tabular}

Gbr 35. Tampilan Laporan Pembelian Barang

C. Pengujian Porgram

Pengujian terhadap program yang dibuat menggunakan blackbox testing yang fokus terhadap proses masukan dan keluaran program [9]. 
TABEL I

HASIL PENGUJIAN FORM LOGIN

\begin{tabular}{|c|c|c|c|c|c|}
\hline No & $\begin{array}{c}\text { Skenario } \\
\text { Pengujian }\end{array}$ & $\begin{array}{l}\text { Test } \\
\text { Case }\end{array}$ & $\begin{array}{c}\text { Hasil } \\
\text { yang } \\
\text { diharap } \\
\text { kan }\end{array}$ & $\begin{array}{c}\text { Hasil } \\
\text { Pengujian }\end{array}$ & $\begin{array}{c}\text { Kesim } \\
\text { pulan }\end{array}$ \\
\hline 1. & $\begin{array}{l}\text { Username } \\
\text { dan } \\
\text { Password } \\
\text { tidak diisi } \\
\text { kemudian } \\
\text { klik tombol } \\
\text { login }\end{array}$ & $\begin{array}{l}\text { Userna } \\
\text { me: } \\
\text { (kosong } \\
\text { ) } \\
\text { Passwor } \\
d \text { : } \\
\text { (kosong } \\
\text { ) }\end{array}$ & $\begin{array}{l}\text { Sistem } \\
\text { akan } \\
\text { menolak } \\
\text { akses user } \\
\text { dan } \\
\text { menampil } \\
\text { kan pesan } \\
\text { "usernam } \\
\text { e atau } \\
\text { password } \\
\text { yang anda } \\
\text { masukkan } \\
\text { salah" }\end{array}$ & $\begin{array}{l}\text { Sesuai } \\
\text { harapan }\end{array}$ & Valid \\
\hline 2. & $\begin{array}{l}\text { Mengisi } \\
\text { salah satu } \\
\text { form dan } \\
\text { salah satu } \\
\text { form } \\
\text { kosong } \\
\text { kemudian } \\
\text { klik tombol } \\
\text { login }\end{array}$ & $\begin{array}{l}\text { Userna } \\
\text { me: user } \\
\text { Passwor } \\
d \text { : } \\
\text { (kosong } \\
\text { ) }\end{array}$ & $\begin{array}{l}\text { Sistem } \\
\text { akan } \\
\text { menola } \\
\mathrm{k} \text { akses } \\
\text { user } \\
\text { dan } \\
\text { menam } \\
\text { pilkan } \\
\text { pesan } \\
\text { "data } \\
\text { tidak } \\
\text { boleh } \\
\text { kosong" }\end{array}$ & $\begin{array}{l}\text { Sesuai } \\
\text { harapan }\end{array}$ & Valid \\
\hline 3. & $\begin{array}{l}\text { Mengisi } \\
\text { salah satu } \\
\text { form dan } \\
\text { salah satu } \\
\text { form } \\
\text { kosong } \\
\text { kemudian } \\
\text { klik tombol } \\
\text { login }\end{array}$ & $\begin{array}{l}\text { Userna } \\
\text { me: } \\
\text { (kosong } \\
\text { ) } \\
\text { Passwor } \\
d \text { : user }\end{array}$ & $\begin{array}{l}\text { Sistem } \\
\text { akan } \\
\text { menolak } \\
\text { akses } \text { user } \\
\text { dan } \\
\text { menampil } \\
\text { kan pesan } \\
\text { "data } \\
\text { tidak } \\
\text { boleh } \\
\text { kosong" }\end{array}$ & $\begin{array}{l}\text { Sesuai } \\
\text { harapan }\end{array}$ & Valid \\
\hline 4. & $\begin{array}{l}\text { Mengetikan } \\
\text { username } \\
\text { dan } \\
\text { password } \\
\text { dengan data } \\
\text { yang benar } \\
\text { kemudian } \\
\text { klik tombol } \\
\text { login }\end{array}$ & $\begin{array}{l}\text { Userna } \\
\text { me: user } \\
\text { Passwor } \\
\text { d: user }\end{array}$ & $\begin{array}{l}\text { sistem } \\
\text { menerima } \\
\text { akses } \\
\text { login, } \\
\text { kemudian } \\
\text { langsung } \\
\text { menampil } \\
\text { kan Menu } \\
\text { Utama }\end{array}$ & $\begin{array}{l}\text { Sesuai } \\
\text { harapan }\end{array}$ & Valid \\
\hline
\end{tabular}

\section{KESIMPULAN}

Perancangan Sistem Informasi Akuntansi Pembelian Barang pada PT Bangun Prestasi Bersama Jakarta bertujuan untuk mempermudah user dalam menangani proses pembelian antara pihak perusahaan dengan supplier. Dengan menggunakan aplikasi ini, diharapkan proses transaksi pembelian yang terjadi antara pihak perusahaan dengan supplier akan dapat di organisir dengan baik sehingga efektifitas dan efisiensi kerja perusahaan meningkat, mengurangi kesalahan dalam pengolahan data, dan keamanan data pembelian barang terjamin dan tidak mudah hilang.

\section{REFERENSI}

[1] G. W. Sasmito, "Penerapan Metode Waterfall Pada Desain Sistem Informasi Geografi Industri Kabupaten Tegal," Jurnal pengembangan IT, vol. 2, no. 1, p. 8, 2017.

[2] T. Sutabri, Analisa Sistem Informasi, Yogyakarta: Andi Offset, 2012.

[3] J. Hutahean, Konsep Sistem Informasi, Yogyakarta: deepublish, 2016.

[4] A. W. Ekarini, Sistem Informasi Akuntansi: Pengertian, Tujuan, Fungsi dan Contoh Materi. 2020. https://centrausaha.com/sistem-informasi-akuntansipengertian-tujuan-fungsi-contoh-materi/

[5] Sukamto, R. A., \& Shalahuddin, M. Rekayasa Perangkat Lunak Terstruktur dan Berorientasi Objek edisi Revisi. Bandung: Informatika. 2018.

[6] Fridayanthie, E. W., \& Mahdiati, T. Rancang Bangun Sistem Informasi Permintaan ATK Berbasis Intranet (Studi Kasus: Kejaksaan Negeri Rangkasbitung). Jurnal Khatulistiwa Informatika, IV(2), 126-138. 2016.

[7] Puspita, A., Fahmi, M., \& Yuningsih, Y. Perancangan Dan Pembuatan Aplikasi E-Learning Menggunakan Model Waterfall Pada Sekolah Menengah Atas. Jurnal Riset Informatika, 1(4), 173-180. https://doi.org/10.34288/jri.v1i4.94. (2019).

[8] Sukmaindrayana, A., \& Sidik, R. (2017). Aplikasi Grosir Pada Toko RSIDIK Bungursari Tasimalaya. Jurnal Manajemen Informatika, 4(2), 31-40. Retrieved from https://www.cambridge.org/core/product/identifier/CBO97811 07415324A009/type/book part

[9] Maulana, A., Kurniawan, A., Keumala, W., Sukma, V. R., \& Saifudin, A. (2020). Pengujian Black Box pada Aplikasi Penjualan Berbasis Web Menggunakan Metode Equivalents Partitions (Studi Kasus: PT Arap Store). Jurnal Teknologi Sistem Informasi Dan Aplikasi, 3(1), 50 https://doi.org/10.32493/jtsi.v3i1.4307

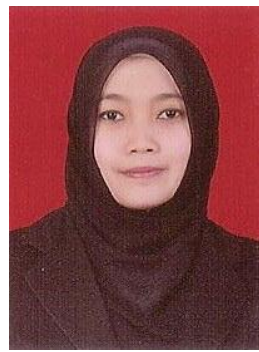

Ari Puspita,M.Kom. Tahun 2011 lulus dari Program Strata Satu (S1) Program Studi Sistem Informasi STMIK Nusa Mandiri. Tahun 2015 Lulus dari Magister Ilmu Komputer Program Pascasarjana STMIK Nusa Mandiri. 


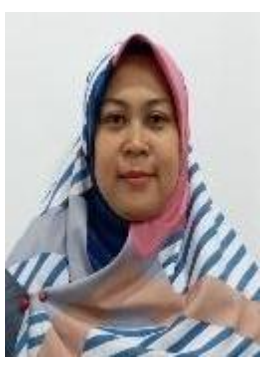

Yuyun Yuningsih, M.Kom adalah dosen pada program studi Sistem Informasi STMIK Nusa Mandiri. lus Program Strata Satu (S1) Program Studi Sistem Informasi STMIK Nusa Mandiri pada tahun 2013 dari pendidikan Lulus Pasca Sarjana STMIK Nusa Mandiri pada tahun 2015.

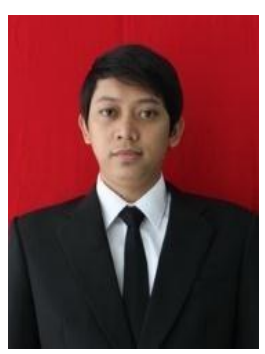

Muhammad Fahmi, M.Kom. Tahun 2011 lulus dari Program Strata Satu (S1) Program Studi Sistem Informasi STMIK Nusa Mandiri. Tahun 2014 Lulus dari Magister Ilmu Komputer Program Pascasarjana STMIK Nusa Mandiri.

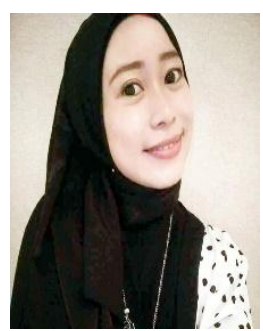

Yuli Wahyuni. Tahun 2008 lulus dari Program Strata Satu (S1) Program Studi Teknik Elektro Institut Teknologi Nasional Malang. Tahun 2010 Lulus dari Magister Teknik Elektro Program Pascasarjana Universitas Brawijaya Malang. 